DOI: $10.19195 / 2084-5065.39 .2$

\title{
Z problematyki przestępczości zorganizowanej w prawie francuskim*
}

\author{
JOANNA BRZEZIŃSKA \\ Katedra Prawa Karnego Materialnego \\ Wydział Prawa, Administracji i Ekonomii Uniwersytetu Wrocławskiego
}

\section{Definicja}

Wstępna analiza francuskich regulacji prawno-karnych mających na celu bezpośrednie przeciwdziałanie przestępczości zorganizowanej pozwala na stwierdzenie, że ustawodawca z dużym opóźnieniem przystapił do podjęcia konkretnych działań wymierzonych przeciw tej formie niezwykle groźnej patologii. Dopiero bowiem w ustawie n ${ }^{\circ}$ 2004-204 z 9 marca 2004 r. ${ }^{1}$, obserwując nieustanny rozwój nowych przejawów przestępczości, uznał za stosowne odnieść się w sensie formalnym do kwestii przestępczości zorganizowanej. Niniejsza regulacja dała podstawę do przedstawienia penalizowanego zjawiska z dwóch perspektyw: instytucjonalno-formalnej (jako patologii, która realizowana jest zwykle w ramach określonej organizacji przestępczej zrzeszającej pewną grupę osób) lub strukturalnej (jako okoliczność kwalifikująca przestępstwa)².

* Niniejszy artykuł został przygotowany w ramach projektu badawczego finansowanego przez Narodowe Centrum Nauki; decyzja nr DEC 2012/07/D/HS5/00605 — kierownik projektu dr J. Brzezińska.

1 J. Pradel, Droit pénal général, Paris 2010, red. Cujas, s. 370; Por. Cass. Crim., 15 sept. 2004; Bull. Crim. 2004, nº 213.

${ }^{2} \mathrm{~W}$ toku rozważań doktrynalnych Izba Kryminalna w orzeczeniu z 15 września 2004 roku stwierdziła, że działanie w ramach zorganizowanej grupy przestępczej sta- 
Odnosząc się do pierwszego ujęcia, warto zaznaczyć, że w sensie formalnym przestępczości o charakterze zorganizowanym zwykle odpowiada określona zbiorowość sprawców, „skupionych” w ramach organizacji przestępczej, która najczęściej przybiera postać zorganizowanej grupy przestępczej. Jej charakterystyka została przedstawiona w art. 132-71 C.P. ${ }^{3}$, który stanowi, że organizacja taka to „każde sformowane ugrupowanie lub porozumienie zawarte w celu przygotowania jednego lub kilku przestępstw, charakteryzowane przez jedno lub kilka znamion (tychże przestępstw - podkr. J.B.)". Przy czym przygotowanie przestępstw/a bywa interpretowane w tym przypadku szeroko jako ogół czynności, których celem jest ułatwienie dalszych etapów realizacji znamion czynu zabronionego (np. rozpoznawanie miejsc, gdzie może zostać popełniony czyn zabroniony, sporządzanie planów działania, nadzorowanie sprawców wykonawczych $)^{4}$. Zwykle grupa przestępcza posiada pewną strukturę (choć nie zawsze jest ona ściśle ustalona) ułatwiającą wykonywanie wyznaczonych działań (co wyklucza ich przypadkowość) przez osoby, które są jej członkami ${ }^{5}$. W orzecznictwie podkreśla się, że istnienie zorganizowanej grupy przestępczej opiera się na strukturze, w której każda osoba pełni rolę specyficzną i uzupełniającą w stosunku do innych jej członków posiadających zróżnicowane kompetencje. Ponadto nie jest wymagane, by grupa taka miała długotrwały charakter, dopuszczalne jest popełnienie przez nią wyłącznie jednego przestępstwa ${ }^{6}$.

We francuskim kodeksie karnym brak jest definicji zjawiska przestępczości zorganizowanej, funkcjonuje ono jedynie w odniesieniu do organizacji, których celem jest popełnienie poważnych przestępstw. Jed-

nowi okoliczność kwalifikująca, która znajduje zastosowanie wobec współsprawców i współdziałających bez konieczności występowania premedytacji u każdego z nich. Jednak każdy z nich musi mieć świadomość przynależności do struktury o przestępczym charakterze. Por. Cass. Crim., 15 sept. 2004; Bull. Crim. 2004, nº 213.

3 Art. 132-71 C.P.: „Constitue une bande organisée au sens de la loi tout groupement formé ou toute entente établie en vue de la préparation, caractérisée par un ou plusieurs faits matériels, d'une ou de plusieurs infractions". http://www.legifrance. gouv.fr/affichCodeArticle.docidTexte=LEGITEXT000006070719\&idArticle=LEGIARTI000006417489\&dateTexte $=\&$ categorieLien $=$ cid $($ dostęp: 20.03.2016).

4 P. Gattegno, Droit pénal spécial, red. Dalloz, Paris 2007, s. 238.

5 G. Cornu, Vocabulaire juridique, red. Puf, Paris 2009, s. 108.

${ }^{6}$ M.-L. Rassat, Droit pénal spécial, Paryż 2006, s. 52-53. 
nak na podstawie ustawy z 9 marca $2004 \mathrm{r}^{7}$ pojęcie to wprowadzono do kodeksu postępowania karnego. Tytuł XXV księgi IV został określony jako Procedura stosowana $w$ odniesieniu do przestępczości zorganizowanej. Pewnym problemem jest jednak nadal brak konkretnej definicji tej kategorii przestępczości, ponieważ we wskazanej sytuacji niejasny pozostaje zakres zastosowania przedmiotowej procedury szczególnej. W tym kontekście w doktrynie francuskiej zaproponowano następujące rozwiązanie. Istnieją dwie zasadnicze kategorie przestępstw, ściśle związane ze zjawiskiem przestępczości zorganizowanej: pierwszą stanowią te $\mathrm{z}$ nich, które zostały popełnione $\mathrm{w}$ zorganizowanej grupie (zgodnie $z$ art. $706-73^{8}$ C.P.P. wśród nich należy wskazać m.in. zabójstwo, handel narkotykami, stręczycielstwo, kradzież, wyłudzenie, porwanie i bezprawne pozbawienie wolności przez zorganizowaną grupę przestępczą, a także przestępstwa związane $\mathrm{z}$ praniem pieniędzy oraz paserstwo ${ }^{9}$ ),

7 http://www.conseil-constitutionnel.fr/conseil-con..c/decision-n-2004-492-dc-du02-mars-2004.897.html

${ }^{8}$ Ze struktury art. 706-73 C.P. wynika, że przestępstwo ma być poważne. Ponadto przestępstwo zorganizowane zakłada wielość uczestników działających w strukturze ciagłej i zhierarchizowanej, pozwalającej planować przestępstwa. Dodatkowo między nimi musi istnieć porozumienie. Poza tym Komisja konstytucyjna w decyzji z 2 marca 2004 potwierdza te cechy i kładzie akcent na premedytację i zorganizowaną strukturę wyróżniającą przedmiotowe organizacje przestępcze. Por. J. Leroy, Droit pénal géneral, s. 154-156; Lexique de termes juridiques, red. Dalloz 2010, s. 95, 242.

9 Art. 706-73: „La procédure applicable à l'enquête, la poursuite, l'instruction et le jugement des crimes et des délits suivants est celle prévue par le présent code, sous réserve des dispositions du présent titre:

$1^{\circ}$ Crime de meurtre commis en bande organisée prévu par le $8^{\circ}$ de l'article 221-4 du code pénal;

$2^{\circ}$ Crime de tortures et d'actes de barbarie commis en bande organisée prévu par l'article 222-4 du code pénal;

$3^{\circ}$ Crimes et délits de trafic de stupéfiants prévus par les articles 222-34 à 222-40 du code pénal;

$4^{\circ}$ Crimes et délits d'enlèvement et de séquestration commis en bande organisée prévus par l'article 224-5-2 du code pénal ;

$5^{\circ}$ Crimes et délits aggravés de traite des êtres humains prévus par les articles 2254-2 à 225-4-7 du code pénal;

$6^{\circ}$ Crimes et délits aggravés de proxénétisme prévus par les articles 225-7 à 225-12 du code pénal;

$7^{\circ}$ Crime de vol commis en bande organisée prévu par l'article 311-9 du code pénal; 
drugą tworzą te, które są nimi z natury (zgodnie z art. $706-74{ }^{10}$ C.P. są to zbrodnie i występki popełnione w zorganizowanej grupie, inne od tych,

$8^{\circ}$ Crimes aggravés d'extorsion prévus par les articles 312-6 et 312-7 du code pénal;

$8^{\circ}$ bis (Abrogé);

$9^{\circ}$ Crime de destruction, dégradation et détérioration d'un bien commis en bande organisée prévu par l'article 322-8 du code pénal;

$10^{\circ}$ Crimes en matière de fausse monnaie prévus par les articles $442-1$ et $442-2$ du code pénal;

$11^{\circ}$ Crimes et délits constituant des actes de terrorisme prévus par les articles 421 1 à 421-6 du code pénal;

$12^{\circ}$ Délits en matière d'armes et de produits explosifs commis en bande organisée, prévus par les articles L. 2339-2, L. 2339-3, L. 2339-10, L. 2341-4, L. 2353-4 et L. 23535 du code de la défense ainsi que par les articles L. 317-2, L. 317-4 et L. 317-7 du code de la sécurité intérieure;

$13^{\circ}$ Délits d'aide à l'entrée, à la circulation et au séjour irréguliers d'un étranger en France commis en bande organisée prévus par l'article L. 622-1 du code de l'entrée et du séjour des étrangers et du droit d'asile;

$14^{\circ}$ Délits de blanchiment prévus par les articles 324-1 et 324-2 du code pénal, ou de recel prévus par les articles 321-1 et 321-2 du même code, du produit, des revenus, des choses provenant des infractions mentionnées aux $1^{\circ}$ à $13^{\circ}$;

$15^{\circ}$ Délits d'association de malfaiteurs prévus par l'article 450-1 du code pénal, lorsqu'ils ont pour objet la préparation de l'une des infractions mentionnées aux $1^{\circ}$ à $14^{\circ}$ et $17^{\circ}$;

$16^{\circ}$ Délit de non-justification de ressources correspondant au train de vie, prévu par l'article 321-6-1 du code pénal, lorsqu'il est en relation avec l'une des infractions mentionnées aux $1^{\circ}$ à $15^{\circ}$ et $17^{\circ}$;

$17^{\circ}$ Crime de détournement d'aéronef, de navire ou de tout autre moyen de transport commis en bande organisée prévu par l'article 224-6-1 du code pénal;

$18^{\circ}$ Crimes et délits punis de dix ans d'emprisonnement, contribuant à la prolifération des armes de destruction massive et de leurs vecteurs entrant dans le champ d'application de l'article 706-167;

$19^{\circ}$ Délit d'exploitation d'une mine ou de disposition d'une substance concessible sans titre d'exploitation ou autorisation, accompagné d'atteintes à l'environnement, commis en bande organisée, prévu à l'article L. 512-2 du code minier, lorsqu'il est connexe avec l'une des infractions mentionnées aux $1^{\circ}$ à $17^{\circ}$ du présent article;

$20^{\circ}$ (Abrogé).

10 Art. 706-74: „Lorsque la loi le prévoit, les dispositions du présent titre sont également applicables:

$1^{\circ}$ Aux crimes et délits commis en bande organisée, autres que ceux relevant des articles 706-73 et 706-73-1;

$2^{\circ}$ Aux délits d'association de malfaiteurs prévus par le deuxième alinéa de l'article $450-1$ du code pénal autres que ceux relevant du $15^{\circ}$ de l'article $706-73$ ou du $4^{\circ}$ de 
które wskazuje art. 706-73 C.P., a także występki popełnione w związku przestępczym, przewidziane $\mathrm{w}$ art. 450-1, al. 2 C.P., inne niż te określone w art. 706-73 C.P., np. terroryzm czy handel ludźmi). Zatem procedura szczególna z tytułu XXV kodeksu postępowania karnego znajduje zastosowanie do obydwu kategorii określonych powyżej przestępstw. Należy zaznaczyć, że przedstawiony podział jest niezwykle istotny, ponieważ pozwala zwrócić uwagę na zasadnicze przejawy przestępczości zorganizowanej: 1) ciężar gatunkowy przestępstw oraz 2) strukturalną konfigurację sprawczą (wielość sprawców, którzy je realizują) ${ }^{11}$.

Należy zwrócić uwagę, że we francuskim kodeksie karnym wyodrębniono również inną, poza grupą przestępczą, formę organizacji przestępczej, która funkcjonuje jako jedna ze struktur przestępczości zorganizowanej. $\mathrm{W}$ art. $450-1^{12}$ C.P. ustawodawca penalizuje funkcjonowanie związku przestępczego. Mogą za takie zostać uznane nielegalne zbiorowości, których celem jest handel bronią lub ludźmi, albo prowadzące działalność terrorystyczną, przejawiającą się w dokonywaniu zamachów o zróżnicowanym charakterze. Karalność udziału we wskazanej organizacji jest uzależniona od ciężaru przygotowywanego przestępstwa, bez znaczenia natomiast pozostaje aspekt liczebności takiej organizacji. Jeśli związek przygotowuje zbrodnię lub występek zagrożony karą 10 lat więzienia, wówczas udział w nim zagrożony jest karą 10 lat więzienia i grzywną w wysokości 150 tys. €. Jeżeli natomiast celem jego działania jest przygotowanie występku zagrożonego karą co najmniej 5 lat więzienia, wówczas udział w nim jest zagrożony sankcją w wysokości 5 lat więzienia i grzywną 75 tys. €. Udział w związku przestępczym stanowi odrębne od przygotowanego w ramach tej struktury zbrodni lub występku przestępstwo ${ }^{13}$.

l'article 706-73-1 du présent code".; http://www.legifrance.gouv.fr/affichCodeArticle.doidArticle=LEGIARTI000006577781\&cidTexte=LEGITEXT000006071154.

11 G. Lopez, S. Tzitzis, Dictionnaire des scienes criminelles, red. Dalloz, Paris 2004, s. 205-206.

12 Art. 421-2-1 C.P. penalizuje udział w związku sprawców, którego celem jest uczestniczenie lub przygotowanie aktów terroryzmu. Przewidziane w przepisie sankcje są bardziej surowe, zależą od natury przygotowanego przestępstwa.

13 M. Veron, Droit pénal spécial, red. Dalloz, Paris 2010, s. 10-12. 
Zasadnicza rozbieżność teoretyczna, jaka występuje między zorganizowaną grupą przestępczą a związkiem przestępczym w prawie francuskim, dotyczy konsekwencji działania w ramach przedstawionych organizacji przestępczych. W pierwszym bowiem przypadku realizacja znamion przestępstwa $\mathrm{w}$ strukturze o charakterze zorganizowanym w grupie przestępczej - stanowi okoliczność kwalifikującą ${ }^{14}$. A zatem wszelkie przestępstwa, których katalog określa art. 706-73 C.P. (np. dokonanie w zorganizowanej grupie przestępczej zabójstwa, tortur, aktów przemocy, kradzieży, bezprawnego uwięzienia), popełnione w przedmiotowej konfiguracji przestępczej w postaci zorganizowanej grupy, zagrożone są wyższą sankcją karną ze względu na występowanie wskazanej okoliczności kwalifikującej ${ }^{15}$. Tymczasem działanie w ramach związku przestępczego (art. 450-1 C.P.) stanowi odrębne, od realizowanego w takiej formie czynu zabronionego, przestępstwo. Nie jest to zatem nigdy okoliczność kwalifikująca, choć sprawca de facto będzie ponosił odpowiedzialność zarówno za działanie w ramach związku przestępczego, jak również za przestępstwo, które w takiej formie popełnił.

Z perspektywy kryminologicznej przestępczość zorganizowana wymaga kumulatywnego uwzględnienia szeregu zróżnicowanych aktywności sprawczych: przygotowania planu działania, kooperacji między sprawcami, podziału ról oraz określenia hierarchii między nimi, a także m.in. rozlokowania uzyskanych zysków, itd. Wszystkie te elementy determinują dynamiczny charakter zorganizowanych grup przestępczych, wskazują na powtarzalność nielegalnych zachowań, których zasadniczym celem jest osiaganie znacznych zysków, często na skalę międzynarodową $^{16}$. Spoglądając na przejawy przestępczości zorganizowanej, należy podkreślić, że znamionuje je zdecydowana różnorodność, począwszy od napadów i oszustw poprzez fałszerstwa, handel skradzionymi samocho-

14 Y. Mayaud, Droit pénal général, Paris 2013, s. 444; J. Pradel, Droit pénal général, Paris 2012, s. 383; B. Bouloc, Droit pénal général, Paris 2013, s. 313.

15 H. Renout, Droit pénal général, Bruxelles 2013, s. 149; J. Larguier, P. Conte, P. Maistre du Chambon, Droit pénal général, red. Dalloz, Paris 2008, s. 74; E. Dreyer, Droit pénal général, red. LexisNexis, Paris 2012, s. 618; D. Dechenaud, L'égalité en matière pénale, LGDJ, coll. Bibl. Sc. Crim. 2008, t. 45, nr 54, s. 45.

16 R. Dufour-Gompres, Dictionnaire de la violence et du crime, red. Eres, Paris 1992, s. 94-95. 
dami, fałszowanie pieniędzy, aż do przemytu narkotyków czy prania pieniędzy ${ }^{17}$. Biorąc pod uwagę przykładowo wskazane zachowania podejmowane przez zorganizowane struktury przestępców, należy stwierdzić, że ich zasadniczym celem jest osiaganie maksymalnych korzyści ekonomicznych wszelkimi nielegalnymi sposobami. Ponadto charakter takiej działalności determinuje konieczność wytworzenia specyficznej struktury organizacyjnej (grupy lub związku przestępczego), która zwykle przybiera zorganizowany charakter, funkcjonuje w oparciu o wyznaczone reguły i hierarchiczne podporządkowanie niewystępujące wśród legalnych form organizacji i zrzeszeń funkcjonujących w społeczeństwie. Zwraca się uwagę, że organizacja taka nie ma charakteru stałego, ze względu na konieczność przeobrażeń zachodzących w jej strukturze. Jednocześnie proces globalizacji upowszechnia transgraniczny charakter przestępczości zorganizowanej, sprzyjając jej rozwojowi poza państwem, w którym tworzone są jej pierwotne struktury ${ }^{18}$.

Jak podkreśla A.M. Costa: „Zorganizowane grupy przestępcze pozwalają zrozumieć, w jaki sposób funkcjonuje światowa ekonomia i zaawansowana technologia, które podążają z sobą w parze"19. Tym samym poziom, częstotliwość, skala i zaawansowanie przestępstw komponujących zjawisko przestępczości zorganizowanej stanowią odzwierciedlenie poziomu rozwoju konkretnego społeczeństwa (w sensie węższym) oraz cywilizacji (w sensie szerszym), w której ona występuje.

\section{Tradycyjne przejawy przestępczości zorganizowanej we Francji}

Przyglądając się zjawisku przestępczości zorganizowanej we Francji, należy stwierdzić, że występuje ono na trzech zasadniczych płaszczyznach, dotyczy bowiem nielegalnego obrotu gospodarczego (zwłaszcza wszelkich odmian nielegalnego handlu), aktywności finansowej (transakcje gotówkowe i bezgotówkowe) oraz działań podejmowanych w sieci

17 Ibidem.

18 M. Quéméner, Crmininalité économique et financière. À l'ère numérique, Paris 2015, s. 46.

19 E. Vernier, Techniques de blanchiment et moyens de lutte, Paris 2013, s. 129. 
informatycznej (cyberprzestępczość) ${ }^{20}$. Zróżnicowanie form patologii, które towarzyszą analizowanej przestępczości, jak również metod i środków, którymi posługują się sprawcy, dowodzi, że bez wahania można ją określić mianem najpoważniejszej współczesnej patologii kryminalno-gospodarczej. Jej wielopłaszczyznowość oraz skala nielegalnych zjawisk, które ją współtworzą, powoduje, że próby wyeliminowania tego nielegalnego procederu kończą się niepowodzeniem. Rozwój gospodarki francuskiej oraz wysoki poziom życia społecznego we Francji sprawiają, że skuteczne przeciwdziałanie przestępczości zorganizowanej staje się niemożliwe. A nawet jeśli na pewnych obszarach występuje zminimalizowanie negatywnych skutków, będących wynikiem działania zorganizowanych struktur przestępczych, niemal natychmiast pojawiają się inne, wyrafinowane, lepiej zakamuflowane ${ }^{21}$, a przede wszystkim bardziej zaawansowane nielegalne aktywności przestępcze o wysokim stopniu inwazyjności (np. cyberprzestępczość).

\section{Nielegalny handel}

Pierwszym z obszarów, które w bezpośredni sposób związane są z przestępczością zorganizowana, jest handel środkami odurzającymi. Umożliwia on osiaganie niezwykle wysokich zysków finansowych, a ponadto sprzyja realizowaniu transakcji wybielania kapitału. Niestety, mimo organizowania przez wyspecjalizowane jednostki działań zmierzających do zminimalizowania skali spożycia narkotyków, utrzymuje się stała tendencja wzrostowa w tym zakresie. Wedle statystyk roczne spożycie: konopi indyjskich we Francji osiaga poziom 250 ton, heroiny — blisko tonę, a tabletek extasy waha się w przedziale od 340 tys. do miliona ${ }^{22}$.

Niewątpliwie jednym z przejawów patologicznych zachowań towarzyszących zorganizowanej działalności przestępczej jest także prostytucja. Na terenie Francji istnieją liczne grupy, które zajmują się tą formą działalności. Wśród nich dominują obywatele państw Europy Wschod-

20 M. Quéméner, op. cit., s. 33-34.

21 N. Queloz, Criminalité économiqie et criminalité organisée, „L'Économie politique" 3/2002, nr 15, s. 58 n.

22 J. Pradel, J. Dallest, La criminalité organisée. Droit français, droit international et droit comparé, Paris 2012, s. 46. 
niej, a zwłaszcza Republik powstałych po rozpadzie Związku Radzieckiego (Rosja, Białoruś, Ukraina, Łotwa, Litwa, Estonia) oraz Afryki (Nigeria). Niekiedy takie grupy wykazują charakter wielonarodowościowy. Niezwykle zaawansowany rozwój prostytucji nastapił wraz z ewolucją sieci informatycznych (poprzez dyskretne strony internetowe czy anonse). Aktualnie we Francji rozwija się zwłaszcza prostytucja luksusowa w zróżnicowanych formach ${ }^{23}$.

W przypadku działalności zorganizowanych grup przestępczych zajmujących się nielegalnym handlem samochodami można wskazać dwie zasadnicze tendencje, po pierwsze częstotliwość ich działań wyraźnie spadła. Wedle danych statystycznych w 2009 r. skradziono 128 tys. pojazdów (dla porównania 384 tys. skradziono w 1993 r.) Aktualnie odnajdywany jest co drugi samochód, przy czym szacuje się, że ponad 62 tys. pojazdów trafia do zorganizowanych grup przestępczych (dominują luksusowe marki). Po drugie wyposażanie pojazdów w nowe zabezpieczenia (zwłaszcza elektroniczne) wymusza na sprawcach wyższy stopień specjalizacji w trakcie realizacji kradzieży w odniesieniu do wszystkich kategorii i typów pojazdów. Przemyt samochodów z Francji odbywa się na szeroką skalę w dwóch kierunkach: do państw Afryki Północnej i Południowej oraz na Bałkany ${ }^{24}$.

Należy także zaznaczyć, że jednym z najpoważniejszych obszarów aktywności zorganizowanych grup przestępczych jest handel bronią i materiałami wybuchowymi. Istnieje kilka przyczyn sprzyjających rozwojowi tego nielegalnego obszaru przestępczości zorganizowanej. Po pierwsze „dozbrajanie” nielegalnych grup przestępczych jest jedną z płaszczyzn działań producentów broni ${ }^{25}$. Ponadto w Europie obowiązują przepisy dotyczące neutralizacji posiadania broni palnej, a ich obowiązywanie implikuje przekazywanie wszelkich nadwyżek amunicji do nielegalnego obrotu. $\mathrm{Z}$ analiz organów ścigania wynika, że francuskie

23 G. Aubry, Organisations criminelles et structures répressives: panorama français, „Cahiers de la sécurité” 2009, nr 7, s. 25 n.; J. Pradel, J. Dallest, op. cit., s. 46-48.

24 R. Gassin, Criminologie et savoir sur la sécurité intérieure, „Revue pénitentaire" 2010, s. 485 n.; C. Champeyrache, Les sociétés du crime. Un tour du monde des mafias, CNRS editions 2007.

25 A. Bauer, La criminalité en France. Rapport de l'Observatoire national de la délinquance, Paris 2009, s. 354; J. Pradel, J. Dallest, op. cit., s. 49. 
grupy przestępcze zaopatrują się w broń i substancje wybuchowe pochodzące zwłaszcza z Jugosławii (np. karabiny typu Kałasznikow) oraz Bośni. Największy problem w handlu bronią stanowi łatwy oraz szeroki dostęp organizacji przestępczych do pozyskania zarówno tradycyjnego uzbrojenia (zwłaszcza z obszarów byłych konfliktów zbrojnych, choć także od wyspecjalizowanych organizacji), jak również nowych rodzajów broni, co zwiększa poważnie stopień zagrożenia publicznego bezpieczeństwa obywateli. Aktualnie pojawia się we Francji jeszcze inny, niezwykle dramatyczny wymiar handlu bronią i materiałami wybuchowymi, jakim pozostaje swobodne dysponowanie amunicją przez zorganizowane grupy realizujące akty terrorystyczne.

\section{Przestępczość finansowa}

W przypadku przestępczości zorganizowanej istnieją dwie zasadnicze płaszczyzny nielegalnej aktywności finansowej wspomagające jej rozwój. Pierwszą z nich stanowi pranie brudnych pieniędzy, które ze względu na swoją specyfikę zyskuje charakter transgraniczny (zwykle gotówka jest lokowana poza terytorium Francji, zwłaszcza w tzw. rajach finansowych ${ }^{26}$ ). Faza wstępna prania pieniędzy polega na przygotowaniu przedmiotowego procederu przede wszystkim poprzez rozlokowanie kapitału o nielegalnym pochodzeniu (przykładowo poprzez transfer kapitału, zabieg ten umożliwia zniwelowanie ryzyka wykrycia zjawiska prania brudnych pieniędzy) ${ }^{27}$. Wśród sposobów transferu kapitału można wskazać między innymi: przemyt, transfer dóbr luksusowych, przekazy elektroniczne i inne usługi on-line, czy cyber-pranie. Drugi etap prania pieniędzy stanowi tzw. lokowanie, które jest realizowane poprzez wprowadzenie do systemu finansowego nielegalnych środków płatniczych przede wszystkim poprzez ich wpłaty na konta bankowe. Trzecia faza określana jest jako maskowanie i odbywa się poprzez ukrycie rzeczywistego źródła pieniędzy, które są transferowane na konta rozlokowane w różnych bankach określonego

26 B. Pereira, Blanchiment, soupçon et sécurité financière, „, Revue intenationale de droit économique" 1/2011, t. XXV, s. 43 n.

$27 \mathrm{http}$ //people.exeter.ac.uk/watupman/undergrad/ron/methods\%20and\%20stages. htm; http://www.fatf-gafi.org/pages/faq/moneylaundering/ (dostęp: 21.03.2016). 
państwa lub w różnych państwach. Ostatni etap stanowi integracja, która polega na ostatecznej legalizacji pieniędzy.

Tymczasem poza procederem prania brudnych pieniędzy zdecydowanemu upowszechnieniu uległo we Francji zjawisko fałszowania kart płatniczych. Według danych udostępnionych zwłaszcza przez francuską policję należy odnotować, że w 2008 r. wśród przestępstw o charakterze ekonomicznym i finansowym jedną z najpoważniejszych kategorii przestępstw o charakterze finansowym stanowiło posługiwanie się podrobionymi kartami kredytowymi lub czekami. Spośród ogólnej liczby 354 tys. przestępstw finansowych zanotowano aż 129 tys. przypadków ${ }^{28}$ posługiwania się podrobionymi kartami kredytowymi i czekami (w tym również takimi, które zostały skradzione $)^{29}$. Najczęściej stosowaną metodę realizowania przestępstw z użyciem kart płatniczych we Francji stanowi skimming ${ }^{30}$. Polega on na naklejeniu nakładki bankomatowej w miejscu włożenia karty płatniczej. Jednocześnie kamera ulokowana ponad klawiaturą dystrybutora automatycznego nagrywa kod wpisywany przez klienta. Te dane ulegają utrwaleniu na pasku magnetycznym fałszywej karty płatniczej, która może zostać użyta w sklepach lub dystrybutorach bankomatowych na pieniądze w całej Europie.

\section{Nowe formy przestępczości zorganizowanej - cyberprzestępczość}

Nie istnieje uniwersalna definicja zjawiska określanego jako „cyberprzestępczość"31. Termin ten dotyczy działalności kryminalnej dokonywanej z wykorzystaniem systemu lub sieci informatycznej, a także odno-

28 http://www.police-nationale.interieur.gouv.fr/Organisation/Direction-Centralede-la-Police-Judiciaire/Lutte-contre-la-criminalite-organisee/Office-central-pour-la-repression-de-la-grande-delinquance-financiere (dostęp: 21.03.2016).

29 Etat 4001 annuel, DCPJ, La criminalité en France. Rapport de l'Observatoire national de la délinquance 2009, red. A. Bauer, s. 293-295.

$30 \mathrm{http}: / / w w w . n e x t i n p a c t . c o m / a r c h i v e / 62701$-carte-bancaire-skimming-fraudeterminologie.htm; http://www.lanouvellerepublique.fr/Loir-et-Cher/Actualite/Faitsdiversjustice/n/Contenus/Articles/2014/09/01/Les-escrocs-du-skimming-sevissent-dansla-region-2029344 (dostęp: 21.03.2016).

31 U. Rasmusen, La cybercriminalité, un moyen de fraude sophistiqué, „Cahiers de droit de l'entreprise" 4, janvier 2013, nr 1. 
si się do zachowań, których celem jest nielegalne używanie komputerów i sieci informatycznych. Wedle definicji zaproponowanej przez OECD jest to „każde nielegalne, nieetyczne lub niedozwolone zachowanie, które dotyczy automatycznego przetwarzania danych lub transmisji danych"32. Z kolei cyberprzestrzeń jest definiowana jako płaszczyzna nowej aktywności człowieka, skupiająca powiązania technologiczne, informacyjne i telekomunikacyjne, która generuje nadużycia wynikające z nielegalnego wykorzystania systemów informatycznych oraz zintegrowanych procedur i mechanizmów kontroli ${ }^{33}$.

We Francji termin „,cyberprzestępczość” jest interpretowany rozszerzająco i dotyczy nie tylko przestępstw popełnianych z wykorzystaniem nowoczesnych technologii, ale również obejmuje inne nielegalne przejawy aktywności sprawców, którzy posługują się w tym celu informatycznymi nośnikami danych (np. oszustwa za pomocą kart płatniczych). Przeciwdziałanie tej formie przestępczości zorganizowanej jest określane jako walka z niewidzialnym wrogiem, gdyż miejscem realizacji nielegalnych aktywności pozostaje sieć informatyczna, stąd też ryzyko ich ujawnienia jest w zasadzie niewielkie (w porównaniu ze skalą, na jaką są dokonywane). Wedle najnowszego francuskiego raportu dotyczącego cyberprzestępczości z 2014 r. obejmuje ona „ogół przestępstw popełnionych lub usiłowanych z zastosowaniem środka lub systemu informatycznego lub komunikacyjnego, w szczególności Internetu"34.

Aktualnie podkreśla się, że cyberprzestępczość jest niezwykle niebezpiecznym zjawiskiem, po pierwsze dlatego, że umożliwia dokonywanie zróżnicowanych przestępstw w sposób zakamuflowany, poprzez posługiwanie się złożonymi procedurami i środkami informatycznymi. Po drugie stosowane przez sprawców metody mogą nie tylko prowadzić do zakłóceń lub zniszczenia urządzeń informatycznych, lecz pozwalają na nielegalne gromadzenie danych osobowych (tzw. danych wrażliwych), stając się polem do kolejnych nadużyć i wyłudzeń, zwłaszcza w sektorze

32 E.A. Caprioli, La lutte contre la cybercriminalité en question, „La Semaine Juridique Edition Générale" 13, Avril 2015, nr 15, s. 460; M. Quéméner, op. cit., s. 34.

33 M. Vivant, Cybermonde; droit et droits des réseaux, JCP 1996, s. 3969; M. Quéméner, op. cit., s. 51-52.

34 M. Quéméner, op. cit., s. 37 
finansowym ${ }^{35}$ (karty płatnicze czy przelewy internetowe nie wymagają kontaktu między podmiotami realizującymi transakcję, co wzmaga nielegalne zachowania).

W celu ochrony podmiotów będących użytkownikami sieci informatycznej wskazuje się na konieczność zastosowania następujących środków ostrożności: 1) identyfikację przesyłanej dyspozycji (autentyfikacja) w celu sprawdzenia właściciela komputera, który ją emituje (co eliminuje nadawanie informacji przez podmioty nieupoważnione), 2) sprawdzenie, czy dyspozycja nie została zmodyfikowana w trakcie transmisji, 3) ochronę przekazu danych do nadawcy ${ }^{36}$. Należy także zaznaczyć, że wskazane zachowania mogą jedynie ograniczyć nadużycia, które dokonywane są w sieci, nie stanowią natomiast metody ich wyeliminowania. Przyczyną tego stanu rzeczy jest stosowanie zróżnicowanych operacji pozwalających na trwały kamuflaż nielegalnych aktywności prowadzonych w Internecie.

\section{Prawne środki zwalczania przestępczości zorganizowanej}

Obowiązujące we Francji regulacje dotyczące przeciwdziałania przestępczości zorganizowanej można podzielić na dwie zasadnicze grupy. W pierwszej znajdują się akty krajowe, z kolei do drugiej należy zaliczyć uregulowania międzynarodowe.

Ustawa ${ }^{\circ}$ 2004-204 określana jako Prawo Perben II $^{37}$, promulgowana została w 2004 r. Jej celem było stworzenie katalogu środków prawnych i procesowych, pozwalających na zwalczane przestępczości zorganizowanej $\mathrm{w}$ ustawodawstwie francuskim. Wprowadzenie nowej regulacji miało na celu przede wszystkim rozszerzenie katalogu okoliczności kwalifikujących ${ }^{38}$, zwłaszcza w odniesieniu do działalności podejmowanej $\mathrm{w}$ strukturach zorganizowanych (takich jak grupa prze-

35 C. Aghroum, Les mots pour comprendre la cybercriminalité. Et profiter sereinement d'Internet, red. Lignes de reperes, Paris 2010, s. 218.

36 M. Quéméner, op. cit., s. 49.

37 https://www.legifrance.gouv.fr/affichTexte.do?cidTexte=JORFTEXT00000024 9995\&dateTexte=20040310; http://www.cairn.info/revue-etudes-2005-2-page-175.htm (dostęp: 22.03.2016).

38 J. Pradel, J. Dallest, op. cit., s. 139; Y. Mayaud, op. cit., s. 444. 
stępcza), jak również związane z tym zaostrzenie kar wymierzanych za niektóre przestępstwa popełnione w powołanych okolicznościach.

Zasadniczym efektem nowej regulacji miała być przede wszystkim harmonizacja polityki prawno-karnej oraz podjęcie skutecznej walki z przestępczością zorganizowaną w sposób najbardziej widoczny. W tym celu wprowadzono następnie dwa kolejne dokumenty z dnia 2 września 2004 r. ${ }^{39}$ Pierwszy z nich był poświęcony dyspozycjom proceduralnym, drugi natomiast dotyczył kwestii ekonomicznych i finansowych. Jak podkreślano, zwalczanie przestępczości zorganizowanej jest możliwe poprzez zaangażowanie znacznej grupy wysoko wyspecjalizowanych podmiotów, rozszerzenie kompetencji organów ścigania oraz wprowadzenie nowych metod operacyjnych ${ }^{40}$. Ponadto zwrócono uwagę na konieczność określenia bardziej efektywnych sposobów i metod zwalczania przestępczości ekonomicznej i finansowej. W tym celu uznano, że niezbędne jest wzmocnienie procedur kontroli celnej, nie tylko w sensie formalnym, ale również z perspektywy regulacji kodeksu celnego (wprowadzenie nowych przepisów). Ponadto wskazywano na konieczność wzmacniania kontroli wobec takich form aktywności, które mogą prowokować działania kryminogenne o charakterze finansowym (np. udział w grach, czy zakładach liczbowych $)^{41}$.

Przechodząc do regulacji o charakterze międzynarodowym, należy podkreślić, że Francja jest sygnatariuszem Konwencji Narodów Zjednoczonych dotyczącej międzynarodowej przestępczości zorganizowanej z 29 września 2003 r. ${ }^{42}$, która stanowi jeden z najważniejszych instrumentów prawnych zmierzających do jej zwalczania na arenie międzynarodowej. Zgodnie z postanowieniami niniejszej Konwencji państwo francuskie zobowiązało się do powstrzymywania wszelkich przejawów przestępczości zorganizowanej, takich jak: pranie brudnych pieniędzy,

39 http://www.textes.justice.gouv.fr/dossiers-thematiques-10083/loi-du40304-dite-perben-ii-10187/liste-des-textes-legislatifs-et-reglementaires-10973.html (dostęp: 22.03.2016).

40 http://www.textes.justice.gouv.fr/art_pix/circulaire020904crimorg.pdf (dostęp: 22.03.2016).

41 http://www.textes.justice.gouv.fr/art_pix/circulaire02092004dispositions.pdf (dostęp: 22.03.2016).

42 https://www.unodc.org/pdf/cld/TOCebook-f.pdf (dostęp: 22.03.2016). 
handel ludźmi (zwłaszcza w odniesieniu do kobiet i dzieci), przemyt narkotyków, nielegalne wytwarzanie i obrót i broną palną i amunicją. Ponadto strona francuska uczyniła zapewnienie o zachowaniu odpowiednich środków ochrony wobec ofiar przedmiotowych przestępstw. Konwencję uzupełniają trzy Protokoły dodatkowe (Protokół o zapobieganiu, zwalczaniu oraz karaniu za handel ludźmi, Protokół przeciwko przemytowi migrantów drogą lądową, morską i powietrzną, Protokół przeciwko nielegalnemu wytwarzaniu i obrotowi bronią palną, jej częściami i komponentami oraz amunicją), które zostały przyjęte przez Francję w całości, wskazując na wzmocnienie jej dążeń do zwalczania wszelkich przejawów przestępczości zorganizowanej, także poprzez rozszerzanie współpracy międzynarodowej.

\section{Wnioski}

Spoglądając na przestępczość zorganizowaną we Francji, można wskazać aktualnie dwie zasadnicze grupy jej przejawów o charakterze:

— materialnym (np. pranie pieniędzy, kradzieże, nielegalny handel) oraz

— niematerialnym (np. nielegalne transakcje bezgotówkowe; luki w prawie, które sprzyjają podejmowaniu nielegalnych działań umożliwiających pogłębianie kryminogennych zachowań w ramach przestępczości zorganizowanej).

Zarówno pierwsza, jak i druga kategoria aktywności może prowadzić do konkretnych materialnych (straty finansowe państwa), jak i niematerialnych rezultatów (np. ubożenie społeczeństwa), implikując niezwykle zaawansowane straty.

Przejawy zachowań kryminogennych w strukturach przestępczości o charakterze zorganizowanym pozostają niezwykle heterogeniczne, jednak należy zaznaczyć, że ulegają one swoistej specyfikacji w tym sensie, że pewne ich kategorie występują z wyższym stopniem nasilenia na terytorium określonego państwa. Proces ten jest wynikiem kumulacji szeregu uwarunkowań gospodarczych, ekonomicznych czy społecznych. Jest kwestią oczywista, że na terenie Polski występuje zarówno proceder handlu narkotykami, jak i kradzieży dóbr luksusowych. Jednocześnie należy 
stwierdzić, że skala tych przestępstw jest zupełnie inna niż we Francji, zwłaszcza ze względu na wyższe kwoty ogólne dokonywanych operacji (w państwach rozwiniętych niektóre z nich w oczywisty sposób nie budzą podejrzeń, w Polsce natomiast wzbudzają one szczególną czujność organów nadzoru finansowego lub organów ścigania).

Analiza aktywności ustawodawcy francuskiego, mająca na celu przeciwdziałanie zjawisku przestępczości zorganizowanej, dowodzi, że mimo iż stosunkowo późno doszło do wykreowania norm, których celem było powstrzymanie przedmiotowej patologii, obecnie można je, w ograniczonym zakresie, odnaleźć w kodeksie karnym ${ }^{43}$, kodeksie postępowania karnego oraz w ustawach szczególnych. Ustawodawca, wprowadzając regulację ustawową z 2004 r. skoncentrował się na zaostrzeniu odpowiedzialności karnej za działanie w zorganizowanej grupie przestępczej w przypadku określonej kategorii najpoważniejszych przestępstw. Jednocześnie dominujące wydaje się przekonanie, że choć pozytywnie należy ocenić podjęcie wysiłków legislacyjnych, zjawisko przestępczości zorganizowanej nadal pozostaje jedną z najpoważniejszych patologii o niezwykle zróżnicowanych przejawach i szerokim zasięgu (zarówno terytorialnym, jak i gospodarczym). Można bowiem bez przesady stwierdzić, że występuje ono na obszarze całej Francji i dotyka w zasadzie wszystkich sektorów gospodarki (handel podrobionymi towarami, fałszowanie pieniędzy, pranie brudnych pieniędzy, handel ludźmi, prostytucja itd.). Wydaje się zatem, że konieczne pozostaje nieustanne wzmacnianie i rozszerzanie wszelkich przejawów działań organów państwowych odpowiedzialnych za zwalczanie analizowanego procederu, jak również rozszerzenie kontroli na takie obszary aktywności, które mogą generować zachowania o charakterze przestępczym (np. sprawdzanie podejrzanych transakcji finansowych lub handlowych).

Nie ma wątpliwości, że przestępczość zorganizowana ewoluuje, a precyzując, ewoluują jej przejawy. Rozwój nowych technologii przyczynia się do różnicowania metod działania sprawców, czego najlepszą egzemplifikacją pozostaje cyberprzestępczość. Skutki tej nowej formy działalności przestępczej mogą być niesłychanie negatywne. Naruszenie

43 Nadal nie wypracowano obowiązującej, jednolitej definicji przestępczości zorganizowanej. 
systemów operacyjnych, a także sterowanie poszczególnymi urządzeniami, a nawet całymi sieciami informatycznymi, powoduje dostęp do zróżnicowanych danych, a także umożliwia przejęcie kontroli np. nad systemami bezpieczeństwa, a w konsekwencji nad strukturą państwa. Wydaje się, że ten przejaw przestępczości zorganizowanej stanowi o jej zaawansowanym rozwoju w ujęciu najbardziej negatywnym. Dysponowanie informacjami utrwalonymi na serwerach przez zorganizowane struktury przestępcze otwiera nieograniczone możliwości paraliżowania prawidłowego funkcjonowania nie tylko poszczególnych instytucji (banki, instytucje para-finansowe czy administracyjne), ale może doprowadzić w przyszłości do zahamowania prawidłowego rozwoju gospodarczego państwa. Tym samym cyberprzestępczość stanowi obecnie najgroźniejszy przejaw przestępczości zorganizowanej również z tego powodu, że podejmowanie działań mających na celu przeciwdziałanie przedmiotowej patologii odbywa się w sieci, co znacznie utrudnia zidentyfikowanie podmiotów, które prowadzą tego rodzaju aktywność. Stanowi więc przejaw nierównej walki podejmowanej z niewidzialnym wrogiem.

\section{On the issues of organized crime in French law}

\section{Summary}

The purpose of this article is to characterize organized crime from the perspective of French law in three aspects. As the first one, was presented the analysis of the definition of the studied phenomenon, noting that its penalization in French law took place just in 2004. Next, criminal behavior connected with the organized crime was identified and systematized in the following categories: illegal trade, financial crimes, cybercrimes. The third area of analysis covers the indication of a catalogue of measures undertaken in order to fight against the subject pathology. In the conclusions it was underlined that taking into account the heterogeneous character of organized crime and the new methods of its spreading, it is impossible to completely eliminate this phenomenon, as well as minimize it, for the above mentioned reasons, may present significant difficulties.

Keywords: organized crime, financial crimes, cybercrimes, illegal trade. 